\title{
Just Say No to 360s: Hip-Hop's Claim of Economic Exploitation
}

\begin{abstract}
This chapter focuses on how independent hip-hop artists in the post-golden era resist economic exploitation from mainstream culture and major corporations. Indie musicians make the grievance that major labels benefit at the expense of performers and hence are highly exploitative. Their unfair treatment is predominantly reflected in the contracts acts sign with major labels. This has repercussions for artists in numerous facets of the music industry: (1) advances/forwards, (2) control of copyrights, (3) artistic direction and relations with A\&R, (4) touring, merchandising, and advertising deals, and (5) radio stations, media, and press. Finally, some hip-hop artists make the claim that creating and maintaining independent record labels helps mitigate economic exploitation, controls record label oversight, and serves for the betterment of the hip-hop community.
\end{abstract}

Keywords Economic exploitation - Corporatization · 360 degree contracts - Advances and forwards - Artist and relations (A\&R)

Forbes magazine reported that Strange Music's Tech N9ne made an estimated 7.5 million dollars in 2012, which was more than mainstream artists 50 Cent, Mac Miller, and Rick Ross (Greenburg 2013). They wrote that Tech N9ne attributes a large part of his success to building a strong fan base without the help of a major record label. His business model,

(C) The Author(s) 2019

C. Vito, The Values of Independent Hip-Hop in the Post-Golden Era, https://doi.org/10.1007/978-3-030-02481-9_3 
which includes a deal with Isolation Network's independent distribution company Fontana, ultimately produces high-profit margins with relatively low cost; as noted in "Crybaby" (2008). Tech N9ne's success has traditionally been seen as an exception to the case, as indie labels have traditionally owned only $10-15 \%$ of the market share (Day 2011). Yet recent studies have shown that this number is steadily increasing as independents now make up as much as 30\% of the market share (Moore 2013).

In addition to asserting cultural differences from major record labels (see Chapter 2), independent hip-hop artists of this genre from 2000 to 2013 also resist economic exploitation from them in various ways. Indie musicians claim that the majors profit at the expense of performers and hence are highly exploitative, which is reflected in the contracts acts sign with large corporations. This exploitation has repercussions for artists in numerous facets of the music industry: (1) advances/forwards, (2) corporate control of copyrights, (3) control of the artistic direction and relations with the Artist and Repertoire Department (A\&R), (4) touring, merchandising, and advertising deals, and (5) radio stations, media, and press. Finally, some musicians argue that creating and maintaining independent record labels helps mitigate economic exploitation, controls record label oversight, and better serves the hip-hop community.

\section{The “Takeover” Part I:}

\section{Independent Artists Claim Exploitation by the Majors}

Independent hip-hop artists in the post-golden era bring attention to the persistent problem of economic exploitation by major record labels. They point to the corporatization of hip-hop culture as highly exploitative. Also, they claim that record contracts, which include artist development deals and 360 degree contracts (also known as multiple rights deals), generally favor large corporations and take advantage of the musician.

\section{The Beginnings: Major Labels Corporatize Hip-Hop and Its Music}

From 1979 to its pinnacle golden era in the mid-1990s, hip-hop experienced a meteoric rise to popularity. Johnson (2008) believes that the golden era was filled with lyrical mastery, innovation in beat production, diversity in style and content, and a push toward 
popular media. Within this shift, large corporations were able to corporatize hip-hop music into a commodity sold in the mainstream market. The culture then saw a shift toward homogenization in musical content and cultural influences as it became predominantly consumed by whites in American culture (Myer and Kleck 2007; Rose 2008).

Subsequently, hip-hop saw a decline in one hit wonders as companies invested in musicians and albums that conformed to a standardized model of music production to ensure their investments were secure and profits were maximized (Myer and Kleck 2007). Much of their risk was mitigated by buying out smaller labels that already created a profitable business model. For example, Bad Boy Records, which housed powerhouse signees such as the Notorious B.I.G., Ma\$e, Puff Daddy, and the LOX, was bought out by Sony BMG once they obtained enough capital and parity to contend for record sales with larger corporations. Sony BMG was eventually able to increase their profit margins by financially backing a credible brand name such as Bad Boy. With this corporatization, musicians began to lose control of their copyright ownership as record contracts transferred the ownership of rights to sell and promote music from the artist to the label (Rose 2008). In the post-golden era, hip-hop saw its music being concentrated in the hands of the few, mostly elite white men, that held positions of power in the entertainment industry (Chang 2005; George 2005; Myer and Kleck 2007).

Indies also complain that the majors act as venture capitalists that provide them with up-front capital in exchange for the opportunity to exploit their music and culture for monetary gain. They assert that corporations do not put their interests first, but rather are concerned with profit, growth, stability, and brand name recognition. Macklemore LLC's Macklemore and Ryan Lewis write of their experiences with companies attempting to corporatize their music. In "Jimmy Iovine" (2012a), they recall that on the verge of signing a contract, they "felt a cold hand grab on the back of my neck." Their song depicts the importance of Jimmy Iovine, co-founder of Interscope Records, in bringing hip-hop to the mainstream. Iovine has been credited with signing Tupac Shakur and financially backingDeath Row Records, signing multiplatinum acts such as Dr. Dre and Eminem, and co-launching the successful headphone brand "Beats by Dre" (Fricke 2012). They write that those higher up on the corporate ladder, such as Jimmy Iovine, lure musicians onto their label with the promise of success without revealing their desire to exploit their music to 
maximize profits. They believe that companies dupe acts into believing they are concerned for their well-being when in reality Macklemore and Ryan Lewis describe it as a cold and unscrupulous place ripe with failure for many who get signed.

Musicians who do align themselves with large corporations find it difficult to obtain a profit due to exploitation from the label. Jamla Records' Rapsody writes in "Believe Me" (2012a) that the industry is an organizational structure with the few powerful elite maintaining control of the industry, while many artists at the bottom struggle to gain their attention. She believes that this structure hurts musicians as they sell their music to corporations who are not concerned with their success but rather with the bottom dollar. Subterraneous' duo Binary Star rap in "Indy 500" (2000a) that "if you ever finish first a platinum trophy is risen, your prize money? ...your staff of two dozen got dibs in." They contend that corporations, which have a traditional organizational format and large bureaucratic structure, require that management and staff receive a cut of the profit before the performers get paid. Ironically, those in power are put in a position to make financial gains despite not creating the music themselves. This leads many acts to claim that the music industry is highly detrimental for them.

\section{Major Label Contracts: A Site of Economic Exploitation}

While there is much debate as to the status of artists as independent contractor or employee (Goldstein 2013), the onus is nonetheless put on the signee to fulfill their contractual agreements in exchange for a payment set by the employer. Thus, this section will discuss two prominent contracts record companies offer: Artist Development contracts and 360 degree contracts. Indies have viewed these deals as highly exploitative for the signee, as the contracts take advantage of musicians by utilizing their music for the purpose of maintaining long-term profits for the company.

\section{Artist Development Contracts}

An estimated 43,000 demos are sent to the three major record labels a year. Based on those demos, an estimated 500 record deals are offered per year. Of those 500 record deals, an estimated 100 albums are actually released from these new artists (Avalon 2011). In order to minimize 
risk and costs, "Artist Development" deals are often offered from music publishers and labels in place of standard record deals. Traditional artist development deals occur when an unsigned act creates a contractual agreement with a music publisher to license songs for them. The main job of the music publisher is to help them get signed to a label in exchange for a percentage of their future profits.

Similarly, major record companies also offer artist development deals to musicians directly in hopes that they can get in the green from future profits. They often lure acts into these contracts with the promise of financial backing from the company, for example, to fund equipment purchases (Brabec and Brabec 2007). In addition, they are promised that the label will take control of management and publishing to aid them in their career. The long-term goal of artist development deals for labels is to develop the act (Stahl and Meier 2012), and if they become successful to have first rights to eventually sign a long-term deal with said act.

Viper Records' Immortal Technique argues that these AD deals are not beneficial. Instead, they act as a short-term contract with little benefit to the signee. He raps in "Obnoxious" (2003d), "I take a piss on a development deal from Sony, or Def Jam, cause you like all of the rest, man." He raps that $\mathrm{AD}$ contracts are highly exploitative on numerous fronts. These deals usually require an investment up front from the signee. For example, half of the fee for creating a demo is usually paid up front while other half is contingent upon completion. Also, they may be forced to record their demo with in-house producers at the label's studio. Upon completion, the company usually holds option clauses, or the ability to negotiate for a full contract, discontinue relations, or match any offer from another label.

These types of deals put the onus on signees to create a product concordant with the company's values. Conversely, the company spends very little capital in comparison to their potential long-term reward. If the musician becomes successful, they are able to recoup their profits and potentially keep them on their label. If the artist is not successful, the record company is noncommittal and incurs little risk and cost.

\section{Degree Contracts}

Large record companies have traditionally made earnings from selling physical copies of music in the form of compact discs. After hip-hop's boom in the late 1990s, the music industry took a sharp turn toward the 
digital age in the early 2000s (Karubian 2009). The digital age exponentially increased the salience of digital downloads and direct distribution models via online Web sites. First, the creation of online programs such as Napster and Kazaa created illegal P2P (person to person) music file sharing which promoted easier access to digital content. Also, easy access to Torrent Web sites such as Torrentz and The Pirate Bay have allowed for illegal music downloading online. Second, Apple's iTunes also provided access to legal digital downloads. Third, streaming music formats such as Pandora and Spotify allowed users to pay a monthly fee to access a large library of music. Finally, direct distribution models were utilized by artists to directly sell their music via online Web sites. Companies such as TuneCore (Byrd 2014) and CD Baby eliminated the need for a record label by selling music online direct to consumer. Many corporations faced lost profits due to the decline in CD sales and the proliferation of online distribution (Ostrove 2014). By 2014, the RIAA reported that music sales declined approximately 65\% since its high point in 1999 (Resnikoff 2014). Yet, companies have currently adapted to the changes in the industry by reasserting control over online sales.

An immediate response to the destabilization of the music industry by the spur of the digital era was the formation of 360 degree contracts, also known as multiple rights contracts. These contracts allow record companies to extract profits from various aspects of the signees' revenue stream to account for the downturn in record sales in the digital era, which was generally not part of traditional recording deals. These aspects can include any facet of their career, hence the term 360 degrees, such as merchandising, touring, and commercial endorsements. They first appeared in an early form in 2002 with Robbie Williams' deal with EMI (Marshall 2013; Stahl and Meier 2012). Other acts such as the Pussycat Dolls, Paramore, Madonna, and Lady Gaga have subsequently signed 360 degree deals (Arts Law Centre of Australia 2008). As Day (2011) indicates, these contracts have become standard practice in the music industry. By 2010, over half of Warner Music Group's acts were signed to 360 deals (Ostrove 2014).

Indies claim that 360 degree contracts have been highly detrimental to artists' careers. They argue that these contracts are highly exploitative and limit the economic profits one can make. Subterraneous' rap duo Binary Star writes in "New Hip-Hop" (2000b) that "labels need to chill with they Clark Gable deals." Clark 
Gable, an American actor signed to MGM, was once dubbed the "King of Hollywood" after his performance in Gone with the Wind (Lifetime 2016). Binary Star refers to the idea that companies profit from actors', such as Clark Gable, popularity and success. Within hip-hop, this has become more salient as record companies obtain their profit by extracting profits from every aspect of the musicians' careers.

Traditionally artists and labels shared equitable arrangements that benefitted both parties. For example, the label would agree to inherit the costs of the artist (which could include personal expenses, recording costs, promotion and marketing, video production, and promotional touring) in exchange for a percentage of their copyrights (rights to ownership of their music) in perpetuity. Once the musician repays the label for these expenses, both parties would share in future net profits. With most of the profits being earned from record sales, signees would willingly agree to allow companies to obtain a large percentage, for example, $85-90 \%$, of net profits while they would take what was left, for example, 10-15\% (Day 2010; Marshall 2013). They would willingly engage in these circumstances because they did not make a majority of their profits from record sales. Most of their revenue streams came from netting a large percentage of cash from touring, merchandise, and advertising deals.

With the rise of 360 degree deals, indies argue that these contracts further exploit the musician and ultimately make them disposable if they do not create profits for the corporation. Rhymesayers Atmosphere raps in "One of a Kind" (2002): "I still say fuck a major label till it limps, put your deal up our table and we'll show you who's the pimp." Sound in Color's Blu and Exile write in "I am" (2007b) that turning over all rights to the record label makes artists "the next generation of slaves." Referencing De La Soul's "I Am I Be," Blu and Exile question how they can make profits, or "papes," for the label while still being unable to pay their rent. Like Atmosphere, they understand that record companies are not concerned with their well-being and will go at lengths to maximize their profits.

In order to adapt to the changes in the market large corporations altered music contracts to dip into alternative streams of revenue to account for lost profits in royalties through record sales. These 360 degree contracts hand over to the company corporate control of all aspects of the signee. This includes profits not only from royalties of record sales, but touring, merchandise, advertising and endorsement deals. Indies have responded by arguing that these deals are highly 
exploitative and objectifying as the labels now control every aspect of their career. They thus have the burden to be successful in all facets of the music industry just to make scant profits compared to their labels.

\section{The “TakeOver” Part II: \\ How Major Record Labels Reached Every \\ CORNER OF THE INDUSTRY}

Economic exploitation by the majors is not merely reflected in the contractual agreements between artist and label. The corporatization and changing nature of contracts permeates into all aspects of the industry. In the following sections, I will demonstrate how indies from 2000 to 2013 have made this argument in five facets: (1) advances and forwards, (2) copyright control, (3) artistic direction and relations with A\&R, (4) touring, merchandise, and advertising deals, and (5) radio/media and press. I discuss each of these in turn.

\section{Advances and Forwards}

Less than $5 \%$ of artists that sign with a major label will ever make a profit (Avalon 2011). Record companies understand this risk and thus 360 degree contracts offer financial support to maximize a musician's potential for success. One way labels provide assistance to performers is through advances or forwards in the form of a loan to help them create, distribute, and promote their music. This includes providing capital for music production, packaging, distribution, music video production, marketing, and repertoire. They also pay the musician a salary up front in exchange for their services. For instance, a company may spend up to 1 million dollars on various expenses as Table 3.1 illustrates (IFPI 2016).

A popular technique for many companies is to give forwards and loans to unsigned or independent acts that have generated enough buzz in the industry and have shown a proof of concept for their music. Major labels capitalize on this by providing them with cash flow to fund their music and even pay them a substantial fee up front, leading many acts to be enticed by large lump sums of money that make them feel they have "made it." 
Table 3.1 Record label expenses

\begin{tabular}{ll}
\hline Record label expenses & Dollar amount \\
\hline Personal artist expenses & $\$ 200,000$ \\
Recording costs & $\$ 200,000$ \\
Promotion and marketing & $\$ 300,000$ \\
Video production & $\$ 200,000$ \\
Promotional touring & $\$ 100,000$ \\
Total & $\$ 1,000,000$ \\
\hline
\end{tabular}

While the money that is fronted to them appears to be a sign of financial and commercial success, indies remain leery of this process. Rap collective Hieroglyphics states on "Make Your Move" (2003) that signing to a label like Jive may appear beneficial from the outset as they may receive $\$ 250,000$ up front (Ostrow 2010). Many times artists will use part of this advance to purchase a home, car, jewelry, or other material goods. But as Macklemore LLC's duo Macklemore and Ryan Lewis reiterate through a mocking of "Jimmy Iovine" (2012a) himself, they write: "we'll give you a hundred thousand dollars, After your album comes out, We'll need back that money that you borrowed." Similar to Hieroglyphics, Macklemore and Ryan Lewis understand that the cash received is a loan that will have to be paid back to the company before incurring further profits. In addition, receiving an advance means that they are now controlled by the label and must adhere to any provisions outlined in the contract. Any violations of such provisions allow the corporation to null and terminate the contract all together, leaving many musicians to give up all future revenue to the company until the advance is repaid.

In many cases, musicians never see a profit but instead remain in debt during their careers. For example, Rapper "A" may make $10 \%$ of $500,000 \mathrm{CD}$ purchases or downloads at $\$ 9.99$. The total profit from sales is 5 million dollars, with the artist earning $\$ 500,000$. But because the record label fronts the musician with 1 million dollars, which includes a $\$ 200,000$ advance (see Table 3.1), they first recoup those expenses before the act nets a profit. The musician is still in debt to the record company for $\$ 500,000$ and would still need to sell an additional 500,000 albums just to break even (Guidry 2014).

If these costs are eventually repaid, the label still owns a majority of the profits from record sales and also owns a percentage (anywhere from $5-50 \%$ ) of alternative revenue streams due to 360 degree contracts (Day 
2011). Their justification is that the music industry is risky and their investments must net a certain level of return. The 360 degree contracts have detrimental effects for the artist as they now have no viable means of profit unless they become commercially successful. In the instance that they do become successful, many do not see the amount of profits concurrent with their success. QN5's hip-hop trio Cunninlyngists spit on "Since When" (2006) that "a Maybach and a plaque, is that all you get?...shhhit." Indies understand that advances are alluring to acts as they give the perception of commercial and financial success, but in reality it will take a long time before performers themselves are paid for their labor.

\section{Control of Copyright}

A percentage of profits made from the use of music, in the form of royalties, is traditionally the main source of revenue for major record labels. Royalties are payments in perpetuity made to the owners of music whenever an album is purchased; a song is downloaded or streamed; reproduced by another artist; or performed or played in a public space (Ostrove 2014). Indies express the grievance that major labels' ownership of royalties hinders their ability to see profit in a timely manner. Major corporations offer royalties to musicians, around 10 to 15 points (or percent), off of Standard Retail List Price (SRLP) (Ostrow 2010). But because of advances/forwards taken by the artist, any royalties received will take place after the advance, which can include costs for packaging expenses, free goods, and marketing, is paid off. In many instances, musicians must sell between 100,000 and 500,000 units at Standard Retail List Price (SLRP) before they can get paid any royalties in perpetuity. But even after the advance is paid off, the record company still owns a royalty on all sales made thereafter. Sound in Color's Blu and Exile rap in "Simply Amazin'” (2007a): “it's like you tryn'a take custody of my sound?" As they describe, the record company still owns a royalty on their music, which hinders their long-term profit. Many indies view this stream of revenue as unfair, as acts without a large label can potentially become profitable without a lag time in seeing their share of royalties.

Viper Records Immortal Technique also describes the process in which artists lose in the current distribution of profits from royalties. $\mathrm{He}$ writes in "Industrial Revolution" (2003a) that "you're better off 
begging for twenty points from a label.” Musicians who sign to mainstream labels negotiate points off of royalties from record sales. They may receive anywhere from 10 to 15 points on major label contracts, but must also split these percentages with songwriters, managers, and producers (Bylin 2010). This could potentially leave artists with 5-7 points after paying out their partners (Keif 2006). Thus, Immortal Technique points out they truly only see a very small portion of the profits made from their own music. Conversely, companies take about 20 points in royalties, with the rest of the points going to other branches such as marketing, free goods, and distribution/packaging. In total, around $60 \%$ of the profits from royalties are allocated directly to the company with an additional $25-30 \%$ being allocated toward distribution, which is also typically owned in-house (Cosper 2016). He continues to spit on "Industrial Revolution" (2003a), "now these parasites wanna percent of my ASCAP." On the track, Immortal Technique describes his rise to fame in the industry. Once he made a name for himself, he claims that labels again try to get in on his profits. For instance, labels also dip into a percentage of ASCAP-protected royalties. ASCAP (American Society of Composers, Artists, and Publishers) acts as a not-for-profit organization that protects copyrights when music is publicly performed or played (ASCAP 2016). In addition to taking a cut of royalties for units sold, corporations also control a portion of royalties, potentially $10-30 \%$ (Day 2011), from ASCAP whenever the song is performed or used. Indies essentially make the argument that giving up control of copyright is highly skewed toward long-term profit for the corporation and not the creators of the music.

\section{Artistic Direction and Relations with A\&R}

When an act signs to a label, they also hand over partial control of their name to the company. Many indies make the claim that being signed to the majors enables the company to take control of the artistic direction and behavior of the musician. As often stipulated by their contract, they must get approval from management on their brand name, persona, and music created. As Subterraneous' rap duo Binary Star raps on "Indy 500" (2000a), "no suggestions on directions, they're controlling your wheel." The label also has significant influence on how musicians behave, which ranges from touring, interviews, radio, and television promotions, and advertising deals. Viper Records' Immortal Technique echoes these 
sentiments in the song "Freedom of Speech" (2003c), rapping that being "signed to the majors" is contingent on "switch[ing] up his politics and chang[ing] his behavior." On the track, he argues that companies are highly invested in their private and public image. Concurrently, acts signed to large companies see this as highly constrictive as they have to negotiate and navigate their own values and beliefs. This leads independents to be reluctant to sign with the majors because of the corporate oversight they face.

A major means of corporate control occurs in the album creation process. The artistic direction is predominantly controlled by the A\&R (Artist and Repertoire) branch of the company. This branch is put in charge of finding new talent that is aligned with their ideals and brand. They also work on song selection, producer choice, recording studio selection, and the setup for the recording process (Negus 2002). Further, they act as a liaison between artist and label (Knab 2010). Indies rap about their hesitancy to trust $A \& R$ for three reasons. $A \& R$ is predominantly concerned with the success of album sales. Subterraneous rap duo Binary star spits on "New Hip-Hop" (2000b) "but you ain't, so stop and listen, platinum sales is not the mission." A\&R helps to create an artist's musical content and thus are highly invested in the music creation process, even if it is at the expense of the message and creativity, which puts an undue pressure on musicians to conform to the record label's practices. Sound in Color's Blu and Exile write of their experiences of depression and stress from corporate oversight in "Dancing in the Rain" (2007c): "trying hard to be an artist, but my A\&R be calling me out my zone into his office...I'm stressing to grip, cause it's hard to make music when this depression exists." The corporate oversight in the music creation process can be unnerving for Blu and Exile who make music for creative reasons. It can also lead to clashes between the artist and $A \& R$, in which $A \& R$ often have the final say.

Homogenization also becomes more frequent as $A \& R$ can filter the music production process and make changes to the final cut of the album. Viper Records' Immortal Technique writes in "The Message and the Money" (2003b): "and to all these bitchass A\&Rs...that keep recycling marketing schemes and imagery." He contends that artist creativity is stifled while interacting and negotiating with the upper management. This can temper an act's ability to create new and innovative music in favor of formulaic albums and marketing schemes, which was predominantly seen in the post-golden era. 
Finally, A\&R gets a financial cut of the act's revenues. In addition to paying the label for royalties, A\&R gets a cut of the profits made from album sales. Subterraneous' Binary Star writes on "Indy 500" (2000a) that "you got a crew of two dozen plus an A\&R," which means that they have to be paid first as well. In conjunction with poorly set up contracts by companies, Binary Star believes that the corporate oversight and lack of financial benefit make major record labels an unappealing avenue for success. Indies echo Immortal Technique's sentiments that corporate control by the label, and more specifically A\&R, is objectifying and exploitative akin to colonization when he spits on "Industrial Revolution" (2003a) that: "A\&R's tried jerking me thinking they call shots, offered me a deal and a blanket full of smallpox."

\section{Touring, Merchandise, and Advertising Deals}

With the proliferation of 360 degree contracts, major record labels are able to extract profits from alternative revenue streams (Day 2011). It has become so profitable that concert promoters, such as Live Nation, have even offered 360 deals to acts such as Madonna and Jay-Z. They emphasize touring, merchandising, social media, and endorsement deals, while outsourcing distribution to major labels (Marshall 2013). Indies have rapped about their displeasure with having profits being taken away from three means of cash flow that were traditionally seen as profitable: touring, merchandise, and advertising deals.

Musicians originally netted a large percentage of profits from touring, regardless of whether they are headlining and rake in a majority of the profits or are just opening to build a larger fan base. But getting gigs requieres maintaining relations with managers, promoters, other artists, and fans during the touring process. One arena of exploitation musicians always had to resist is from promoters and venues. Viper Records' Immortal Technique states in "The Message and the Money" (2003b) that promoters are "charging up to $\$ 10$ at the door," and the artists see none of it. His lyrics represent the exploitation many face on tour as they are left to negotiate with numerous individuals out for profit on a nightly basis. Ostrove (2014) points out that promoters, venues, management, and booking can charge around $50 \%$ of the net profits from each show. In addition, performers under 360 degree contracts are left even more vulnerable as the record label takes a cut off the top of their show tours as well. Despite record label management playing a small role in the 
touring process, they are still able to take around $25-30 \%$ of profits made from touring (Gordon 2013).

Acts also face cuts in profit, anywhere from $20 \%$ to as much as $50 \%$ (Marshall 2013), from merchandise sales. They originally made revenue from selling clothing and other "merch" during shows through street teams. This was further exacerbated by online Web sites and social media, which gave musicians motivation to promote their brand name and increase direct sales. But Macklemore LLC's Macklemore and Ryan Lewis on "Jimmy Iovine" (2012a) write of the situations that many major artists face, getting only a third of "merch [sold] on the road," and "money [made] out doing shows," while the manager and booking agent each get "twenty and ten," leaving the artists with " $7 \%$ (of the profits) to split."

Further, many 360 degree contracts stipulate that the record label makes a profit from any outside contracts made with other corporations. Usually, this is in the form of endorsement deals such as Pepsi or Coke, wherein artists might give up to $10-25 \%$ to the record label (Day 2011; Gordon 2013). Due to the company's stake in the musician, they also are keenly aware of their ideologies and actions when they sign endorsement deals. Viper Records' Immortal Technique writes on "Freedom of Speech" (2003c): "I ain't got no motherfuckin deal with Pepsi, no corporate sponsor telling me what to do, asking me to tone it down during the interview." Immortal Technique is directly referencing Ludacris' drop from Pepsi's advertising campaign. Ludacris acted as a spokesperson for Pepsi, but faced criticism from conservative host Bill O'Reilly (Oh 2002). Mainstream acts signed to major labels lose out on a cut of their alternative revenue streams and also face oversight from corporations who attempt to control their image, and subsequently are controlled in their financial fate. In essence, artists experience further exploitation as labels have dipped into profits of touring, merchandise, and advertising.

\section{Radio/Media Outlets and Press}

The practice of payola, or the payment of bribe by companies to be included in "regular airplay," has been banned in the USA (FCC 2015). For example, in 2005 Sony BMG was convicted of illegal payola practices and subsequently paid a 10 million dollar fine (Aldorfer 2005). The underlying logic is to prevent major corporations from obtaining a monopoly of the airwaves. Ideally, this allows for heterogeneity in the 
music played for the public and allows autonomy for the radio stations. Unfortunately, the practice of payola has long been circumvented by the use of independent promoters of the major record labels in the music industry to act as a "middle man" with radio stations. They hire the "indies" to represent them to different radio stations and media outlets, which in turn create profit for the radio stations accepting informal "kickbacks" from the promoters who pay for promoted airtime (Caves 2000). While technically illegal, major corporations can spend anywhere from $\$ 15,000$ to $\$ 100,000$ to get a single played and even $\$ 250,000$ to push for a Top 40 play in the USA (Green 2015; Katunich 2002). Major corporations currently still spend millions of dollars a year promoting their roster on the radio.

The practice of payola acts as a double bind for musicians. It adversely affects mainstream artists as many of them use their advances to fund payola-like practices, which can equate to tens of thousands of USD to promote their singles. These costs for promotion are first recouped through royalties by the labels, which hinders their ability to make a profit and get in the green. Alternatively, this leaves independents economically marginalized as they compete with the vast amount of resources and capital that large labels possess. While technological advances have allowed performers to promote their works online without major support, the emergence of legal online Web sites such as iTunes as an alternative to hard copy CD sales has become increasingly valuable. But iTunes requires fees to sell and stream tracks online and thus favors those who can pay for this service (as mentioned in Jamla Rapsody's "Believe Me" [2012a]). She believes indies do not get love from the radio because they cannot afford payola-like practices to reach Top 40 radio station play. She also understands that iTunes is a venue that requires capital and thus is veered toward acts who possess financial backing similar to that of payola.

In addition, indies express the grievance that radio stations are becoming increasingly interconnected through the process of conglomeration. After the passing of the Telecommunications Act of 1996 by the FCC, the market faced deregulation under the premise that it would allow for increased competition, diversity, and localism. Within two years of its passing 4000 of the 11,000 radio stations changed hands into the conglomerate Clear Channel (Prindle 2003). By 2004 Clear Channel owned much of the radio station market, which included 1200 radio stations, 135 performing venues, 716,000 billboards, and 39 television stations. This made Clear Channel, now iHeartRadio, one of the 
largest corporations in the media industry (Figueroa et al. 2004). Prindle (2003) states that this has also led to greater homogeneity on the radio and acted as the "holy grail" for select artists to garner mass attention. Duck Down's Blue Scholars write in "The Long March" (2005): “clean the Clear Channel out your eardrums and throat." Independents such as Blue Scholars have made the economic grievance that Clear Channel owns much of the radio station market and can control what performers get played, thus leaving independent hip-hop musicians to find alternative means of getting airplay and acquiring concert venues.

Finally, media outlets such as XXL, Vibe, The Source, and Pitchfork create cosigns, or shout-outs and promos for artists' music, to create buzz and improve record sales. They also play a large role in providing information to fans, interviewing performers, and discussing current events and topics of debate (Harrison and Arthur 2011). This gives major press companies the ability to influence musicians' careers and futures. As Sound in Color's Blu and Exile rap on "My World Is" $(2007 \mathrm{~d})$, "and you can only imagine how much passion that I put in this, but some magazines try to rate me on how good it is." On the track, Blu and Exile allude to the notion that they put creative and economic resources into their works, but are constantly under the microscope of magazines and other media outlets. This objectifies artists as they are merely viewed as vessels who create music to be consumed by the masses rather than musicians who are creative. Also, it is even more difficult for indies to overcome negative reviews because of lack of access to payola, marketing, and advertisements. Macklemore LLC's Macklemore and Ryan Lewis share similar sentiments on "Ten Thousand Hours" (2012b), stating "that the people decide to walk with him... regardless of Pitchfork, cosigns I've jumped." In this instance, he recollects how he was overlooked by Pitchfork and by many other media outlets who have not cosigned them. Ultimately, indies claim that major radio and media outlets are highly biased toward major record label success and marginalize many independent record labels and artists.

\section{The Resistance:}

\section{An Age Old Story Made New for Hip-Hop}

Like Tech N9ne, Macklemore LLC's Macklemore and Ryan Lewis have achieved critical acclaim for their independent success in the hiphop industry. Their debut album, The Heist, was released in 2012 and 
reached number two on the Billboard 200 and eventually reached platinum status in 2014. Their album included notable hits such as "Can't Hold Us" featuring Ray Dalton, "Same Love" featuring Mary Lambert, and "Thrift Shop" featuring Wanz. The duo eventually earned 2014 Grammys for Best New Artist, Best Rap Album, and Best Rap Performance (iTunes 2016). Macklemore and Ryan Lewis have noted that they reached success through a small to medium size business model, which is characterized by independently owned record labels that operate with less than 500 employees in the USA (Smith 2012). But this alternative means to success is not a new phenomenon. Instead, the technological advancements and concordant shifts in the marketplace have created a new avenue for independent success despite resistance from large corporations. Indie hip-hop artists find that the small to medium size model can help mitigate economic exploitation and create a viable means of financial and commercial success with less corporate oversight and minimized economic exploitation from the majors.

\section{The Cycle of the Indies}

Perkins (1996) states that underground hip-hop flourished in the Bronx and upper Manhattan in 1979. But as it gained attention from the music industry, it faced rapid corporatization, objectification, and increased inclusion in mainstream culture. Subsequently, Forman (2000) notes that the formation of self-owned record labels has been a response to the formation of bogus 360 degree contracts, management conflicts, and poor economic relations between musicians and labels. The current landscape of the hip-hop community in the post-golden era has seen the rise of artists more familiar with the production and management side of the industry acting as entrepreneurs in the rap game.

But this dialectical struggle between major and independent labels is not new. Lopes (1992) recapitulates Berger and Peterson's notion that the music industry has periods of innovation and diversity followed by periods of homogenization. For example, in the 1920s and 1930s racebased indie companies existed in blues music. Similarly, indie brands such as MoTown and Stax emerged in the post-World War II era (Forman 2000). George (2005) finds independent black music has historically been used by corporate labels to drive popular music as they allow record labels to feel the "pulse" of the public. Once this occurs, large corporations utilize sophisticated modes of production and distribution to 
homogenize consumer tastes for a profit until a new proven commodity emerges.

More recently, 1970s punk music in the USA, the UK, and Australia created a push back toward growing multinational corporations with a DIY (do-it-yourself) approach to the music industry. They emphasized the democratization of music by allowing more artists to own "skin" in the business. Strachan (2007) points out that this DIY ethic is still used by UK indie labels that create a niche market adopting small-scale music production and critiquing global corporate media. In the early 1990s during the golden era, hip-hop utilized a similar approach with the formation of smaller labels such as Ruthless Records, Def Jam, and Tommy Boy (Forman 2000). As Negus (2002) notes, they can create that niche by being closer to their fan base and remaining close to the street, which allows them to stay up to date on the latest sounds, trends, fashions, and dances.

Rappers in the post-golden era have cited the constant presence of the indie movement in hip-hop since its corporatization. Koch Record's KRS-ONE spits on "Nothing New" (2007): "we won't be found man on Billboard or SoundScan, seek me, and you will find." KRS-ONE points to the constant demand of his music by listeners, despite not being recognized by large record sales and downloads. He reminds his audience that the independent movement has been alive and well since hip-hop's inception and can always be found if one looks beyond mainstream music.

In addition, artists have demonstrated their desire to reverse the commodification and corporatization of music production and distribution induced by the majors. Battle Axe Records' Swollen Members rap on the track "Act On It" (2002a): "that were cut, mastered, and released under Battle Axe...it's nice to know that I've been a part of something reversal." Swollen Members reiterate that the hip-hop community is consistently changing the economic landscape of the industry. In particular, they acknowledge these changes through their financial success despite being underrepresented in the market. They emphasize going against the grain by producing records in-house and developing a loyal fan base in the pre-Internet era. Their success has culminated in fomenting a relationship between labels Battle Axe and Suburban Noize Records to increase their brand name (Baller Status 2015). Yet indies pushing back against large corporations and creating an alternative culture is not a new phenomenon, but rather a cyclical one. 


\section{The Changing Nature of the Industry}

While Lopes (1992) states that the music industry faces cycles of diversity and homogeneity, he adds that innovation in popular music depends on the system of development and production used by record companies. For example, labels may incorporate an open system of development while simultaneously maintaining control of the market. In the case of hip-hop, technological changes created the rise of DIY ethics, but continued exploitation through 360 degree contracts and further corporatization have kept major labels salient. Nonetheless, indie musicians and labels have resisted the majors' control by utilizing the changes in the industry to create successful independent business models.

In the late 1990s, independent and underground acts were able to make waves in the music industry with the explosion of the online marketplace. They were now able to circumvent the need for large labels and radio stations that have corporatized the music production process, including music videos, distribution, marketing, and networking (Karubian 2009; McLeod 2005). Leyshon (2001) notes that large corporations could not compete with $\mathrm{p} 2 \mathrm{p}$ shares, online distributions, and online networking, which could all be done independently by musicians. Forbes magazine headliner, Major Record Labels as Dinosaurs (Busch 2012), illustrates how the growth of online music has led to a fragmentation in consumer tastes and a revival in niche indie music.

Strange Music's Tech N9ne and Viper Records' Immortal Technique (Hard Knock TV 2013) state that they originally gained notoriety via local and regional representation, which included street teams building their brand by handing out CDs and merchandise one by one at venues, record stores, and street corners (Forman 2000). But they both understand the changes in the industry and now utilize an online presence to maintain their success. As Ostrove (2014) notes, the days of street teams handing out CDs one by one were in the distant past, as self-release models were more accessible than ever before. For instance, former indie artist Mac Miller released four free online mixtapes between 2007 and 2010. He also toured frequently, posted free music via online music sites such as SoundCloud and DatPiff, and had a large presence through online media sites such as World Star and Twitter. By the time Blue Slide Park was released in 2011, Mac Miller had generated enough buzz to be commercially successful while remaining on Rostrum's indie label. 
Indie artists have openly shown their support for an alternative economic model resistant to major label dependency. YONAS LLC's YONAS writes on "I Could" (2011): "I remember all the people, how they said I wouldn't make it, I just wanna show you that I'm here and I'ma take it." Battle Axe's Swollen Members refer to the "wonderful underworld" on "Breathe" (2002b), who are "tryin' to keep it independent in recruitable times." Swollen Members has stated that they willingly remain in the indie circuit despite being consistently recruited by large corporations. Similarly, Hieroglyphics Imperium's Hieroglyphics write in "Make Your Move" (2003): "starting up companies and keeping the product coming...we gotta get the dough!" Like YONAS and Swollen Members, they emphasize in their lyrics the ability to start indie labels and create an even playing field where they can actually make money and be financially successful without the support of the majors.

Macklemore LLC's Macklemore and Ryan Lewis, exemplars of financial and commercial success while remaining economically independent, highlight their long road to success on "Can't Hold Us" (2012c). On this track they acknowledge their indie status and the grind that they have put in to becoming successful, from working with a four-track audio recorder while traveling on the bus across the city. As Complex notes, Macklemore and Ryan Lewis were able to build a niche fan base using local and regional promotions and utilizing social media to their advantage (Drake 2015). Their success is also shown by their financial gains. On "Ten Thousand Hours" (2012b), they rap: "shit man I'm paying rent, about damn time that I got out of my basement." For Macklemore and Ryan Lewis, they write that this feeling of making money is a burden off of their shoulders after a long road to success. More importantly, many independent musicians like Macklemore and Ryan Lewis can make up to $50 \%$, as opposed to $10 \%$, off of album sales. This translates into high-profit margins once they repay their record labels despite lower album sales (Guidry 2014). They also usually own a high stake in the royalty game, usually earning between $40-75 \%$ compared to mainstream artists earning between 10-15\%. They can even cut out the middleman in 360 degree contracts to earn high rates of return from marketing, promotions, and direct-to-fan activity (Gottfried 2016). In essence, indies have taken advantage of the changes in the music industry's landscape and some have obtained financial and commercial success without the backing of the majors. 


\section{The Resistance: An Economic and Political Message?}

The material conditions underlying music creation and production can illicit political stances by artists as they navigate their careers (Ball 2009). For instance, indie mixtapes and radio stations can spread music outside corporate oversight and free from the filters of mainstream media. Similarly, the underground hip-hop scene can remove them from corporate infrastructure through self-production and performances (Harkness 2012). This separation from large corporations can help spur more critical political stances as they are aware of their self-production and thus can speak freely on their experiences and ideologies. For example, Maher (2005) critically analyzes Dead Prez, a hip-hop duo who has treaded independent waters, as they speak on their ghettocentric and Afrocentric experiences.

Indies alter the dynamics of the music industry as major record labels need to tighten control of their artists to increase their share of the market. This potentially creates a shared awareness among artists and listeners of their ability to resist economic exploitation and take a political stance against corporate America. Subterraneous' Binary Star spits in "Indy 500" (2000a) about the importance of "trying to keep this music to ourselves," rather than "selling out this art for some money." Binary Star understands their political resistance as they create a movement toward independent culture. They state that they refuse to sell out to the mainstream despite others who are willing to give up their culture to corporate America for money and fame. Jamla's Rapsody similarly writes in "Non-Fiction" (2012b) that: "the game is for the taking, this is history in the making." She envisions hip-hop as alive and well, with the game as strong as ever, which challenges popular sentiments that hip-hop is dead. Instead, she realizes that it can still be found in the underground. What remains to be seen is if the indie record labels can create unified grievances about the music industry that translate into social consciousness and social activism. Viper Records' Immortal Technique acknowledges on "The Message and the Money" (2003b) the sentiments of many musicians that independent hip-hop is an important "contribution to the business of hip-hop" and as a result "the more the industry will be forced to change."

\section{Conclusion}

This chapter examines how independent hip-hop artists in my study not only critique cultural domination by corporations, but resist and critique economic exploitation as well. They argue that major record 
labels shape the music industry to maximize their profits at the expense of the artists. More specifically, $\mathrm{AD}$ deals and 360 degree deals aim to exploit all facets of musicians' revenue stream. The exploitation occurs through the following avenues: (1) advances/forwards that artists have to repay, (2) expanded corporate control of copyrights for record companies, (3) control of artistic direction and relations by the Artist and Repertoire (A\&R) Department of the label, (4) loss of profits from tours, merchandising, and advertising deals, and (5) the expanded control of radio stations, media, and press by major labels. Finally, acts choose to create and maintain indie music and take advantage of the technological changes, such as the rise of online music distribution and easier access to music production equipment, in the industry. They hope to attain financial stability while rejecting corporate oversight and control by major corporations. In turn, they have created a political and economic stance against exploitation in the music industry.

\section{REFERENCES}

Aldorfer, Melanie. 2005. "10 Million Payola Settlement." Retrieved April 15, 2016. http://www.cbsnews.com/news/10m-payola-settlement/.

Arts Law Centre of Australia. 2008. "360 Degree Record Deals.” Retrieved April 15, 2016. www.artslaw.com/au/articles/entry/360-degree-record-deals/.

ASCAP. 2016. "About ASCAP." Retrieved April 15, 2016. http://www.ascap. com/about.

Atmosphere. 2002. "One of a Kind." God Loves Ugly. Rhymesayers/Fat Beats. Avalon, Moses. 2011. "What Are the Vegas Odds of Success on Today's Major Label Record Deals?" Retrieved April 15, 2016. www.mosesavalon.com/ what-are-the-vegas-odds-of-success-on-todays-major-label-record-deal/.

Ball, Jared. 2009. "FreeMix Radio: The Original Mixtape Radio Show: A Case Study in Mixtape 'Radio' and Emancipatory Journalism." Journal of Black Studies 39 (4): 614-634.

Baller Status. 2015. "Madchild Recalls Joining Rock Steady Crew, Swollen Members' Success." Retrieved April 15, 2016. http://www.ballerstatus. com $/ 2015 / 06 / 13 /$ madchild-recalls-joining-rock-steady-crew-swollen-members-success/.

Binary Star. 2000a. "Indy 500." Masters of the Universe. Subterraneous Records.

Binary Star. 2000b. "New Hip-Hop." Masters of the Universe. Subterraneous Records.

Blu and Exile. 2007a. "Simply Amazin'." Below the Heavens. Sound in Color.

Blu and Exile. 2007b. "I Am." Below the Heavens. Sound in Color. 
Blu and Exile. 2007c. "Dancing in the Rain." Below the Heavens. Sound in Color.

Blu and Exile. 2007d. "My World Is." Below the Heavens. Sound in Color.

Blue Scholars. 2005. “The Long March.” The Long March. Massline.

Brabec, Todd, and Jeff Brabec. 2007. "Songwriter/Artist Development Deals." Retrieved April 15, 2016. www.ascap.com/Home/Music-Center/aritcles-advice/ascapcorner/corner4.aspx.

Busch, Richard. 2012. "Major Record Labels as Dinosaurs?” Retrieved April 15, 2016. www.forbes.com/sites/richardbusch/2012/03/27/major-record-labelsas-dinosaurs/.

Bylin, Kyle. 2010. "See How Much Indie Artists Make Vs. Label Artists." Retrieved April 15, 2016. www.hypebot.com/hypebot/2010/10/see-howmuch-indie-artists-make-vs.label-artists.html.

Byrd, Ayana. 2014. "How TuneCore Is Making Record Labels Unnecessary." Retrieved April 15, 2016. www.fastcompany.com/3034888/innovation-agents/ how-tunecore-is-making-record-labels-unncessary/.

Caves, Richard. 2000. Creative Industries: Contracts Between Art and Commerce. Cambridge, MA: Harvard University Press.

Chang, Jeff. 2005. Can't Stop Won't Stop: A History of Hip-Hop Generation. New York: St. Martin's Press.

Cosper, Alex. 2016. "How to Divide Percentages with a Record Label." Retrieved April 15, 2016. www.smallbusiness.chron.com/divide-percentages-record-label-39258.html.

Cunninlynguists. 2006. "Since When." A Piece of Strange. QN5/L.A. Underground.

Day, Brian. 2011. "In Defense of Copyright: Record Labels, Creativity, and the Future of Music." Seton Hall Journal of Sports and Entertainment Law 21 (1): 61-103.

Day, Wendy. 2010. "Warning: Hip-Hop Artists Need to Know About Today's 360 Record Deals." Retrieved April 15, 2016. www.hiphopandpolitics.com $/ 2010 / 02 / 05 /$ warning-hip-hop-artist-need-to-knowabout-todays-360-record-deals/.

Drake, David. 2015. "If It Ain't About the Money: Does Hip-Hop Still Need Major Labels?" Retrieved April 15, 2016. www.complex.com/ music/2015/01/hip-hop-major-labels-2015.

FCC. 2015. "The FCC Payola Rules.” Retrieved April 15, 2016. https://www. fcc.gov/consumers/guides/fccs-payola-rules.

Figueroa, Maria, Damone Richardson, and Pam Whitefield. 2004. The Clear Picture on Clear Channel Communications, Inc.: A Corporate Profile, 1-78. Ithaca, NY: Cornell University, ILR School.

Forman, Murray. 2000. "Represent: Race, Place, and Space in Rap Music." Popular Music 19 (1): 65-90. 
Fricke, David. 2012. "Jimmy Iovine: The Man with the Magic Ears." Retrieved April 15, 2016. http://www.rollingstone.com/music/news/ jimmy-iovine-the-man-with-the-magic-ears-20120412.

George, Nelson. 2005. Hip-Hop America. New York: Viking.

Goldstein, Brian Taylor. 2013. "Independent Contractors or Employees: What's in a Name." Retrieved April 15, 2016. http://www.musicalamerica.com/ mablogs $/$ p $=10571$.

Gordon, Steve. 2013. "How to Avoid Getting Completely Screwed by a 360 Deal..." Retrieved April 15, 2016. www.digitalmusicnews.com/2013/07/02/threesixty.

Gottfried, Gideon. 2016. "Everything Is Falling Apart-Luckily." Retrieved April 15, 2016. www.imusiciandigital.com/en/blog/fragmentation-of-themusic-industry/.

Green, Talib Kweli. 2015. "Why I Left the Major Label System: And a Little Bit of What I've Learned in the Music Biz." Retrieved April 15, 2016. https://medium.com/cuepoint/why-i-left-the-major-label-systema0ecfa06ae91\#.60fmop8ap.

Greenburg, Zach O’ Malley. 2013. “Tech N9ne: Hip-Hop's Secret Mogul.” Retrieved April 15, 2016. www.forbes.com/sites/zackomalleygreenburg/ 2013/09/24/tech-n9ne-hip-hops-secret-mogul/.

Guidry, Tony. 2014. "Do the Math: Indie vs. Major-A Rap Breakdown." Retrieved April 15, 2016. www.iamthaconnect.com/2014/11/10/do-themath-indie-vs-major-a-rap-breakdown/.

Hard Knock TV. 2013. "Immortal Technique and Tech N9ne Talk Independent Movement, Technology, Black + Brown.” Retrieved April 15, 2016. www.youtube.com/watch?v=xzR4yDUUgO8.

Harkness, Geoff. 2012. “True School: Situational Authenticity in Chicago's HipHop Underground." Cultural Sociology 6 (3): 283-298.

Harrison, Anthony Kwame, and Craig E. Arthur. 2011. "Reading Billboard 197989: Exploring Rap Music's Emergence Through the Music Industry's Most Influential Trade Publication." Popular Music and Society 34 (3): 309-327.

Hieroglyphics. 2003. "Make Your Move." Full Circle. Hieroglyphics Imperium Recordings.

IFPI. 2016. "How Record Labels Invest." Retrieved April 15, 2016. www.ifpi. org/how-record-labels-invest.php.

Immortal Technique. 2003a. "Industrial Revolution." Revolutionary Vol. 2. Viper Records.

Immortal Technique. 2003b. "The Message and the Money." Revolutionary Vol. 2. Viper Records.

Immortal Technique. 2003c. "Freedom of Speech." Revolutionary Vol. 2. Viper Records.

Immortal Technique. 2003d. “Obnoxious.” Revolutionary Vol. 2. Viper Records. 
Johnson, Christopher. 2008. “Danceable Capitalism: Hip-Hop's Link to Corporate Space." The Journal of Pan African Studies 2 (4): 80-92.

Karubian, Sara. 2009. "360 Deals: An Industry Reaction to the Devaluation of Recorded Music." Southern California Interdisciplinary Law Journal 18: 395-462.

Katunich, Lauren. 2002. "Time to Quit Paying the Payola Piper: Why Music Industry Abuse Demands a Complete System Overhaul." Loyola of Los Angeles Law Review 22: 643-685.

Keif. 2006. "Record Sales: Where Does the Money Go?" Retrieved April 15, 2016. https://bandzoogle.com/blog/record-sales-where-does-the-money-go.

Knab, Christopher. 2010. "Inside Record Labels: Organizing Things.” Retrieved April 15, 2016. www.musicbizacademy.com/knab/articles/insidelabels/htm.

KRS-ONE. 2007. "Nothing New." Hip-Hop Lives. Koch Records.

Leyshon, Andrew. 2001. "Time-Space (and Digital) Compression: Software Formats, Musical Networks, and the Reorganisation of the Music Industry." Environment and Planning 33: 49-77.

Lifetime. 2016. "Biography: Clark Gable Lifetime." Retrieved April 15, 2016. http://www.nytimes.com/movies/person/10097/Clark-Gable/biography.

Lopes, Paul. 1992. "Innovation and Diversity in the Popular Music Industry: 1969-1990." American Sociological Review 57 (1): 56-71.

Macklemore, and Ryan Lewis. 2012a. "Jimmy Iovine." The Heist. Macklemore LLC-ADA.

Macklemore, and Ryan Lewis. 2012b. "Ten Thousand Hours." The Heist. Macklemore LLC-ADA.

Macklemore, and Ryan Lewis. 2012c. "Can't Hold Us." The Heist. Macklemore LLC-ADA.

Maher, George Ciccariello. 2005. "Brechtian Hip-Hop: Didactics and SelfProduction in Post-Gangsta Political Mix-tapes." Journal of Black Studies 26 (1): 129-160.

Marshall, Lee. 2013. "The 360 Deal and the 'New' Music Industry." European Journal of Cultural Studies 16 (1): 77-99.

McLeod, Kembrew. 2005. "MP3s Are Killing Home Taping: The Rise of Internet Distribution and Its Challenge to the Major Label Music Monopoly." Popular Music and Society 28 (4): 521-531.

Moore, Jacob. 2013. "How to Start an Independent Record Label." Retrieved April 15, 2016. www.pigeonsandplanes.com/2013/03/how-to-start-anindependent-record-label/s/be-careful-with-your-cash/.

Myer, Letrez, and Christine Kleck. 2007. "From Independent to Corporate: A Political Economic Analysis of Rap Billboard Toppers." Popular Music and Society 30 (2): 137-148.

Negus, Keith. 2002. "The Cultural Work of Intermediaries and the Enduring Distance Between Production and Consumption." Cultural Studies 16 (4): 501-515. 
Oh, Minya. 2002. “Ludacris Barks Back at Pepsi, O’Reilly; P-Roach Antics Not an Issue for Soda Giant." Retrieved April 15, 2016. http://www.mtv.com/ news/1457357/ludacris-barks-back-at-pepsi-oreilly-p-roach-antics-not-an-issue-for-soda-giant/.

Ostrove, Geoffrey. 2014. "The Political Economy of Financially Successful Independent Artists." Class, Race and Corporate Power 2 (1): 1-22.

Ostrow, Jonathan. 2010. "Indie vs. Major: Which Record Label Contract Is Right for You?" Retrieved April 15, 2016. www.musicthinktank.com/mttopen/indie-vs-major-which-record-label-contract-is-right-for-you.hml.

Perkins, William. 1996. Droppin' Science: Critical Essays on Rap Music and HipHop Culture. Philadelphia: Temple University Press.

Prindle, Gregory. 2003. "No Competition: How Radio Consolidation Has Diminished Diversity and Sacrificed Localism." Fordham Intellectual Property, Media, and Entertainment Journal Law 14 (1): 279-325.

Rapsody. 2012a. "Believe Me." The Idea of Beautiful. Jamla.

Rapsody. 2012b. "Non-Fiction." The Idea of Beautiful. Jamla.

Resnikoff, Paul. 2014. "Why Major Labels Are the Best Thing That Happened to Artists..." Retrieved April 15, 2016. www.digitalmusicnews. com/2014/09/19/major-labels-best-thing-happened-artists/.

Rose, Tricia. 2008. The Hip Hop Wars: What We Talk About When We Talk About Hip Hop-And Why It Matters. New York: Basic Civitas.

Smith, Clyde. 2012. "The Heist: Macklemore \& Ryan Lewis Take DIY Route to iTunes \#1." Retrieved April 15, 2016. http://www.hypebot.com/hypebot $/ 2012 / 10 /$ the-heist-macklemore-ryan-lewis-take-diy-route-to-itunes- 1 . html.

Stahl, Matt, and Leslie Meier. 2012. “The Firm Foundation of Organizational Flexibility: The 360 Contract in the Digitalizing Music Industry." Canadian Journal of Communication 37: 441-458.

Strachan, Robert. 2007. "Micro-Independent Record Labels in the UK." European Journal of Cultural Studies 10 (2): 245-265.

Swollen Members. 2002a. "Act on It." Monsters in the Closet. Battle Axe.

Swollen Members. 2002b. "Breathe." Monsters in the Closet. Battle Axe.

Tech N9ne. 2008. "Crybaby.” Killer. Strange Music.

YONAS. 2011. "I Could." The Proven Theory. City of Dreams. 
Open Access This chapter is distributed under the terms of the Creative Commons Attribution 4.0 International License (http://creativecommons.org/ licenses/by/4.0/), which permits use, duplication, adaptation, distribution and reproduction in any medium or format, as long as you give appropriate credit to the original author(s) and the source, a link is provided to the Creative Commons license and any changes made are indicated.The images or other third party material in this chapter are included in the work's Creative Commons license, unless indicated otherwise in the credit line; if such material is not included in the work's Creative Commons license and the respective action is not permitted by statutory regulation, users will need to obtain permission from the license holder to duplicate, adapt or reproduce the material.

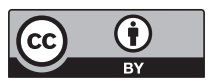

